\title{
Towards better practices of salvage logging for reducing the ecosystem impacts in Mediterranean burned forests
}

\author{
Pere Pons ${ }^{(1)}$, \\ Josep Rost ${ }^{(1-2)}$, \\ Carles Tobella ${ }^{(1)}$, \\ Roger Puig-Gironès ${ }^{(1)}$, \\ Josep M Bas ${ }^{(1)}$, \\ Marc Franch ${ }^{(1)}$, \\ Eduard Mauri ${ }^{(3)}$
}

\begin{abstract}
Introduction
Salvage logging is a forest operation usually aimed at providing economic return after natural or human-induced disturbances that produce damage and mortality to trees. Windstorms, insect outbreaks, disease, droughts, air pollution and fires can be important disturbances at a regional
\end{abstract}

(1) Departament de Ciències Ambientals, Universitat de Girona, 17003 Girona, Catalonia (Spain); (2) Departament de Biociències, Universitat de Vic-Universitat Central de Catalunya, 08500 Vic, Catalonia (Spain); (3) European Forest Institute - Mediterranean Facility, 08025 Barcelona, Catalonia (Spain)

\section{@ Pere Pons (pere.pons@udg.edu)}

Received: Feb 20, 2020 - Accepted: Jun 15, 2020

Citation: Pons P, Rost J, Tobella C, PuigGironès R, Bas JM, Franch M, Mauri E (2020). Towards better practices of salvage logging for reducing the ecosystem impacts in Mediterranean burned forests. iForest 13 : 360-368. - doi: 10.3832/ifor3380-013 [online 2020-08-25]

Communicated by: Davide Ascoli

An average of 213,000 ha of European forest is affected by fire every year, with $90 \%$ of this area corresponding to Mediterranean countries. The timber of the burned forests is usually harvested by clearcutting over large areas to be used mainly as bioenergy. Recent scientific evidence has shown the strong impact that these "salvage logging" practices have on the ecosystem. However, forest owners and companies largely ignore academic debate, and salvage logging decisions are usually taken for economic, practical and emotional reasons. We propose a process to connect scientists and practitioners with the aim of providing evidence-based guidelines to protect biodiversity and ecosystem services, which can be used as a general model. The process involves five steps: (1) to review the available scientific knowledge on post-fire forest management; $(2)$ to synthesize the information to produce a handbook of best practices in Mediterranean burned forests; (3) to provide a tool to help decision-making in post-fire management; (4) to actively disseminate this knowledge to the forest sector; and (5) to fill knowledge gaps with new experimental studies aimed to assess the environmental impact of some of the most feasible management alternatives. The feedback of the forest sector has been obtained along the process, and recommendations for better practices are already being promoted among forest owners by the administration. We suggest that similar processes can be conducted in other socio-environmental contexts to improve the management of disturbed forests and to generalize our knowledge on the topic.

Keywords: Biodiversity, Ecosystem Services, Evidence-based Management, Salvage Logging, Sustainable Logging, Wildfires

scale, while landslides and avalanches affect woodlands more locally (Wolf-Crowther et al. 2011). In many instances, these events are quickly followed by salvage logging over areas of variable extent. Apart from economic reasons, other justifications for cutting damaged forests are adduced. Among them, reducing fuels available for subsequent fires, diminishing the risk of pests and pathogens derived from dead and dying trees, safety concerns from standing dead trees, emotional or aesthetic reasons related to the vision of the damaged forest, or contributing to the ecological recovery of the forest, are common, although their fundamentals may be incorrect (Lindenmayer et al. 2008).

Post-fire salvage logging is currently a common practice in forests and plantations all over the world (Thorn et al. 2018). In Europe, where an average of 213,000 ha of forest was affected by fire every year from 1961 to 2000 (Schelhaas et al. 2003), this form of forest harvesting is widespread. However, the magnitude of postfire salvage logging, in terms of area affected or biomass extracted, has not been quantified to date (San-Miguel-Ayanz, pers. comm.). One can however expect that the vast majority of post-fire logging affects Mediterranean woodlands. In 1980-2018, 100,000 to $1,000,000$ ha were burned each year in five southern countries alone (Portugal, Spain, France, Italy, and Greece San-Miguel-Ayanz et al. 2019), and more than $90 \%$ of European burned forests are found in Mediterranean-climate regions (Schelhaas et al. 2003). Indeed, some studies show that salvage logging can have outstanding effects on regional wood harvesting, specially following large wildfires of thousands of hectares (Cervera et al. 2019). Large scale post-fire salvage logging generates a sort of "spasmodic forestry", which in certain years can amount up to twothirds of the total harvest of a region, and has destabilizing effects on the forest product sector because its timber products can saturate the market (Lindenmayer et al. 2008).

Timber from burned forests is harvested by clearcutting over large areas, so that tens or hundreds of hectares can be logged over continuous land (Pons \& Rost 2017). Usually, all burned and severely damaged trees are cut down. But often undamaged trees within the burned area are also logged, although they are important biological legacies for forest recovery (Franklin et al. 2000). In the twentieth century, before the spread of bioenergy, the harvesting of logs leaving branches on site was likely the prevailing practice in the Mediterranean Basin. Depending on their 
characteristics, logs were processed by sawmills for commercial timber or used for heating (Moreira et al. 2012), whereas branches remained mostly on site. However, in the current century, industrial mobile wood chippers are available. They allow whole trees and remaining canopies to be chipped, after separating the most convenient logs for the sawmill industry. Wood chips are then exported and used as a source of energy for heating or to produce electricity (Nabuurs et al. 2015). When compared to stem-only harvesting, this common operation leaves little woody debris on site.

Important concerns have arisen among the scientific community regarding the effects that the logging of burned forests is having on ecosystem recovery and biodiversity conservation (Lindenmayer et al. 2008, Pons \& Rost 2017). A common finding of conducted research is the increased soil compaction and erosion due to forest operations (Smith et al. 2011, Slesak et al. 2015, Malvar et al. 2017), although adequate contour subsoiling treatments can reduce erosion in relation to non-intervention (James \& Krumland 2018). The removal of woody debris is another concern, because of the small quantity that remains after industrial logging. Yet, woody debris in burned forests provide carbon and nutrient pools for the regenerating ecosystem, increase soil nutrients available for plant growth, facilitate microsite conditions for seedling survival and tree establishment and are critical habitat for many organisms (Boulanger et al. 2010, Bros et al. 2011, Marañón-Jiménez \& Castro 2013, Vacchiano et al. 2014). So, the reduction in snags and charred wood that follows salvage logging has been associated with worse ecosystem regeneration capacities (Marañón-Jiménez et al. 2013). However, the magnitude of impacts depends on the indicators evaluated, the biome studied and, especially, the forestry practices employed. Nonetheless, whether we have appropriate information to decide the best management alternative for every context is questionable. The present works aims to reduce some of these knowledge gaps for Mediterranean-climate forests.

Our main objective was to provide evidence-based guidelines to protect biodiversity and ecosystem services in managed burned forests. The process followed to this aim could be used as a more general model to connect research and practitioners in areas of natural resource management. The next sections of the paper will therefore: (1) discuss the evidence of the impact of post-fire salvage logging on Mediterranean ecosystems; (2) synthesize the process used to connect scientist and practitioners; (3) present recommendations for post-fire forest planning and management at the landscape scale and (4) at the stand level; (5) point out the need of experimental studies comparing the effects of conventional salvage logging, sustainable prac- tices and non-intervention; (6) comment on future improvements in the management of burned forests, and (7) explore some ideas as a conclusion.

\section{Evidence of the ecological impact of post-fire salvage logging}

In recent years, scientific evidence has shown many ecological impacts of logging on burned forests. To compile and synthetize current knowledge, a search was carried out using different bibliographic sources, including Web of Science ${ }^{\oplus}$ (Clarivate Analytics), Google Scholar ${ }^{\circledast}$ and Google Search ${ }^{\circledast}$. The search, conducted in winter-spring 2016, built the foundations of the handbook of best forestry practices explained in the following section. The search was updated in spring 2018 to prepare this paper. We used as search keywords combinations of the terms "fire", "wildfire", "postfire", "post-fire", "salvage logging" and "management". After filtering for references unrelated to the topic, we obtained 165 relevant publications, most of which deal with the ecological consequences of post-fire salvage logging, while others describe the effects of the fire itself. These include scientific papers, book chapters, books and technical reports. Ninety percent of them have been published since 2000. Many publications deal with the regeneration of vegetation and the response of biodiversity indicator groups, while others focus on soil, erosion, nutrients, ecosystem services and future fire risk.

Most of the 165 publications were studies that simply compared non-intervention to a single salvage logging strategy, usually conventional harvesting. However, we identified 30 studies that compared diverse wood management strategies. These studies correspond to only 11 different experiments, conducted in Canada, Greece, Israel, Portugal, Spain and United States, because several experimental areas produced multiple publications (up to 16 for the Lanjarón burned area in Sierra Nevada, Spain Leverkus et al. 2016). In these cases, the measures related to the management of woody debris included using partial logging to retain snags or leaving non-commercial timber on-site. Twenty-two papers (corresponding to five different experiments) compared the effects of at least three logging intensities (Koivula \& Spence 2006, Castro et al. 2010, Azeria et al. 2011, Ritchie et al. 2013), for example 0\%, 25-75\% and $>75 \%$ of trees felled. However, in several studies, trees felled in partial salvage logging were not harvested, so all the wood remained in the burned area, an option that is interesting from a scientific point of view, but unfeasible in most real situations since it needs expenditures but gives no revenues. Another assessed strategy consisted of building piles of debris at 10-m intervals and minimizing machinery movement (Santana et al. 2016). Leaving piles of branches on the soil surface, would be a suitable measure to increase carbon storage, at least in the short term, but might interfere with the recruitment of the forest stand (Santana et al. 2016).

Part of the publications assessed experimental treatments especially devoted to the study, including restoration techniques like direct seeding (García-Morote et al. 2017). However, few studies have analysed practices designed to reduce the environmental impact of post-fire salvage logging. Moreover, not all studies conveniently described the intervention and the magnitude of changes produced by salvage logging, and even fewer compared different treatment intensities, apart from the logging intensities described above. Few of them stated whether the interventions had a commercial goal or could be employed in commercial forestry (see Rost et al. 2010). This can be explained by the fact that many studies are "opportunistic", insofar as the opportunity to study the logging disturbance was taken once it had happened. In other instances, researchers presumably influenced the location of the logged area, but not the practices used by foresters (Izhaki \& Adar 1997).

A recent review of post-disturbance studies, including wildfires and other ecological disturbances, showed that saproxylic organisms are most affected by salvage logging, whereas open-habitat species increase in number (Thorn et al. 2018). In general, publications have stressed the negative environmental effects of post-fire salvage logging, although positive effects have also been found (Rost et al. 2012b). A systematic map is available for the effects of salvage logging on ecosystem services (Leverkus et al. 2018) but systematic reviews and metanalyses of relevant studies are still needed to get a global view of the balance of the consequences of different post-fire management strategies and identify current gaps of knowledge.

\section{The process towards best practices of post-fire salvage logging}

Academic debate is therefore centred on the convenience of harvesting burned forests; on whether it should be done or discarded, but seldom on how it should be done. Often the conclusions are based on the trade-off between environmental impacts and economic benefits. However, forest owners and companies mostly ignore this debate and the decision to conduct salvage logging is usually taken soon after fire. In addition to economic reasons for logging, aesthetic or emotional aspects are fundamental among landowners (Mavsar et al. 2012), who often wish to erase the fire remnants. For example, after the 13,000 ha Alt Empordà fire (Catalonia, Spain) in 2012, several landowners accepted the request of companies for the immediate harvesting of burned pine forests for free. They wanted to get rid of burned trees, the memory of the "fire tragedy", and the large amount of deadwood, 
which is perceived as dangerous for people, promoting insect pests and increasing fire hazard (Pau Costa Foundation 2012). When more than one company were interested on, owners realized that burned wood could be sold. Indeed, the price paid to landowners for chipped biomass can be higher for burned forests, due to the lower costs of operations in these stands with little understorey and to simpler administrative procedures (M. Garfella, Balma Forestal SLP, pers. comm.).

Instead of vilifying post-fire logging per se, the approach of our research team has been to look for potential evidence of best forestry practices aimed at protecting biodiversity and services provided by the ecosystem in regeneration. This evidence should be synthesized and made available in the form of recommendations that should also be tested with specific design (Tab. 1). Based on the bibliographic review described in the previous section and feedback from practitioners, authorities and the forest sector, we produced the "Handbook of good practices in post-wildfire management" (hereafter "the Handbook" - Mauri \& Pons 2016). This first edition, available in Spanish and Catalan versions, was followed by a second revised edition including also an English version (available at http://anifog.wixsite.com/anifog/blank Mauri \& Pons 2019). The Handbook contains the evidence-based fundamentals of management, the guidelines and recommendations for sustainable salvage logging based on the mentioned fundamentals, and a decision-making tool to facilitate decisions depending on the managers' objectives and on the environmental context.

The Handbook deals with salvage logging and short-term post-fire restoration in forests of the Mediterranean basin. It is therefore focused on the wood harvesting activities that can be done immediately after fire and up to three years after. When possible, priority has been given to studies undertaken in forests in the Mediterranean basin (59\% of 165 cited references). When fundamentals or recommendations are based on studies carried out in other regions or biomes, this it is clearly stated. In these cases, forest managers should carefully consider the environmental and socioeconomic characteristics of the area before taking action.

The first part of the Handbook is devoted to the evidence-based fundamentals of management. They provide an ecological justification for the technical recommendations and are also aimed at disseminating current knowledge of post-fire Mediterranean forest dynamics. The fundamentals follow the same structure as the recommendations, in order to easily link both sections of the Handbook. They include seven ecosystem objectives and 20 specific sections (see under "Post-fire forest planning and management recommendations at the stand level").

The second part is the decision-making
Tab. 1 - Summary of the process conducted to generate ecosystem-friendly practices of salvage logging in Mediterranean burned forests. The successive steps, in chronological order, the benefits for practitioners, inputs for the scientific project and deliverables produced are shown in columns. Deliverables \#1 to \#3 correspond to sections of the "Handbook of good practices in post-wildfire management" (Mauri \& Pons 2019), mainly devoted to practitioners. Deliverable \#5 comprises publications targeting academics, practitioners or society as a whole.

\begin{tabular}{|cllll}
\hline Order & Step & $\begin{array}{l}\text { Benefits for the } \\
\text { practitioner }\end{array}$ & $\begin{array}{l}\text { Inputs for the } \\
\text { project }\end{array}$ & Deliverable \\
\hline 1 & $\begin{array}{l}\text { Review of } \\
\text { publications }\end{array}$ & $\begin{array}{l}\text { Knowledge made } \\
\text { accessible }\end{array}$ & Updated information & $\begin{array}{l}\text { Fundamentals of } \\
\text { post-fire ecology and } \\
\text { management }\end{array}$ \\
\hline 2 & Synthesis & $\begin{array}{l}\text { Evidence-guided } \\
\text { actions }\end{array}$ & $\begin{array}{l}\text { Feedback from the } \\
\text { forest sector }\end{array}$ & $\begin{array}{l}\text { Management } \\
\text { guidelines }\end{array}$ \\
\hline 3 & $\begin{array}{l}\text { Conceptual } \\
\text { model }\end{array}$ & Decision support & $\begin{array}{l}\text { Feasibility } \\
\text { assessment of } \\
\text { recommendations }\end{array}$ & Decision-making tool \\
\hline 4 & Dissemination & Time saving & $\begin{array}{l}\text { Connection with the } \\
\text { real world }\end{array}$ & $\begin{array}{l}\text { Pannels, videos, } \\
\text { workshops }\end{array}$ \\
\hline 5 & Field tests & $\begin{array}{l}\text { Evaluation of } \\
\text { operations }\end{array}$ & $\begin{array}{l}\text { Ecological } \\
\text { assessment of } \\
\text { recomendations }\end{array}$ & $\begin{array}{l}\text { Scientific and popular } \\
\text { science publications }\end{array}$ \\
\hline
\end{tabular}

tool. It is a flowchart that guides users by selecting the most convenient forestry recommendations in each context. First, users have to choose among four possible main management objectives: forestry production (Fig. 1), biodiversity conservation, generation of open habitats (Fig. 2) and reduction of fire risk. Different questions have to be answered, that can refer to soil vulnerability, fire severity, felling, hauling and harvesting systems, and other management goals, depending on the selected main objective. General management guidelines are given regarding the management of woody debris, temporal planning, retention areas and soil protection. Finally, the combination of alternatives chosen by the user will lead to numerical codes corresponding to more specific technical recommendations that are explained in the third part of the Handbook.

The management recommendations are aimed at reducing the negative environmental impacts of salvage logging. They are divided into two large blocks: recommendations at landscape and at stand level. While this first division was decided ad hoc, a more detailed distribution of the recommendations into specific subjects was decided post hoc, when the amount of available information was enough to support a group of recommendations for that topic.

A draft of the Handbook was sent to academics and practitioners for feedback to improve the final version. The handbooks in Catalan and in Spanish were published online in summer 2016. In February 2017, a workshop conducted with forest sector stakeholders in Catalonia was used to obtain more opinions about the management recommendations and to test the decisionmaking tool with participants. Finally, a second edition (Mauri \& Pons 2019), including this feedback and information from new scientific studies, was prepared and released in three languages in 2019.

\section{Post-fire forest planning and management recommendations at the landscape scale}

Planning post-fire logging needs a landscape-based approach that covers the whole burned area, since different stands and ecosystems are usually affected and fire perimeters do not match with property boundaries. Secondly, landscape-level planning allows management aimed at producing less fire-prone landscapes (Moreira et al. 2012). Thirdly, this scale of planning allows accommodation of the needs of different species for their conservation. The Handbook gives priority to measures at the landscape level that deal with the initial environmental assessment of burned areas, the amount, spatial distribution and characteristics of burned wood retention and the coordination and compensation of forest owners.

The environmental assessment of burned areas should be done before the first rainy season, and according to specific guidelines (Alloza et al. 2014 developed guidelines for Mediterranean-type ecosystems). The cited guidelines recommend evaluating and mapping potential soil erosion, plant regeneration capacity and fire severity at ground and vegetation levels. Potential soil erosion is an estimation of the amount of soil that can be lost per ha/year and can be found in adequate cartography (in Spain, for example, the maps of the Inventario Nacional de Erosión de Suelos). Plant regeneration capacity is assessed from plant reproductive capacity and speed of regeneration according to forest maps. Fire severity is evaluated by visual inspection soon after fire and according to coarse severity categories at soil, grass, shrub and tree levels or by fire severity 

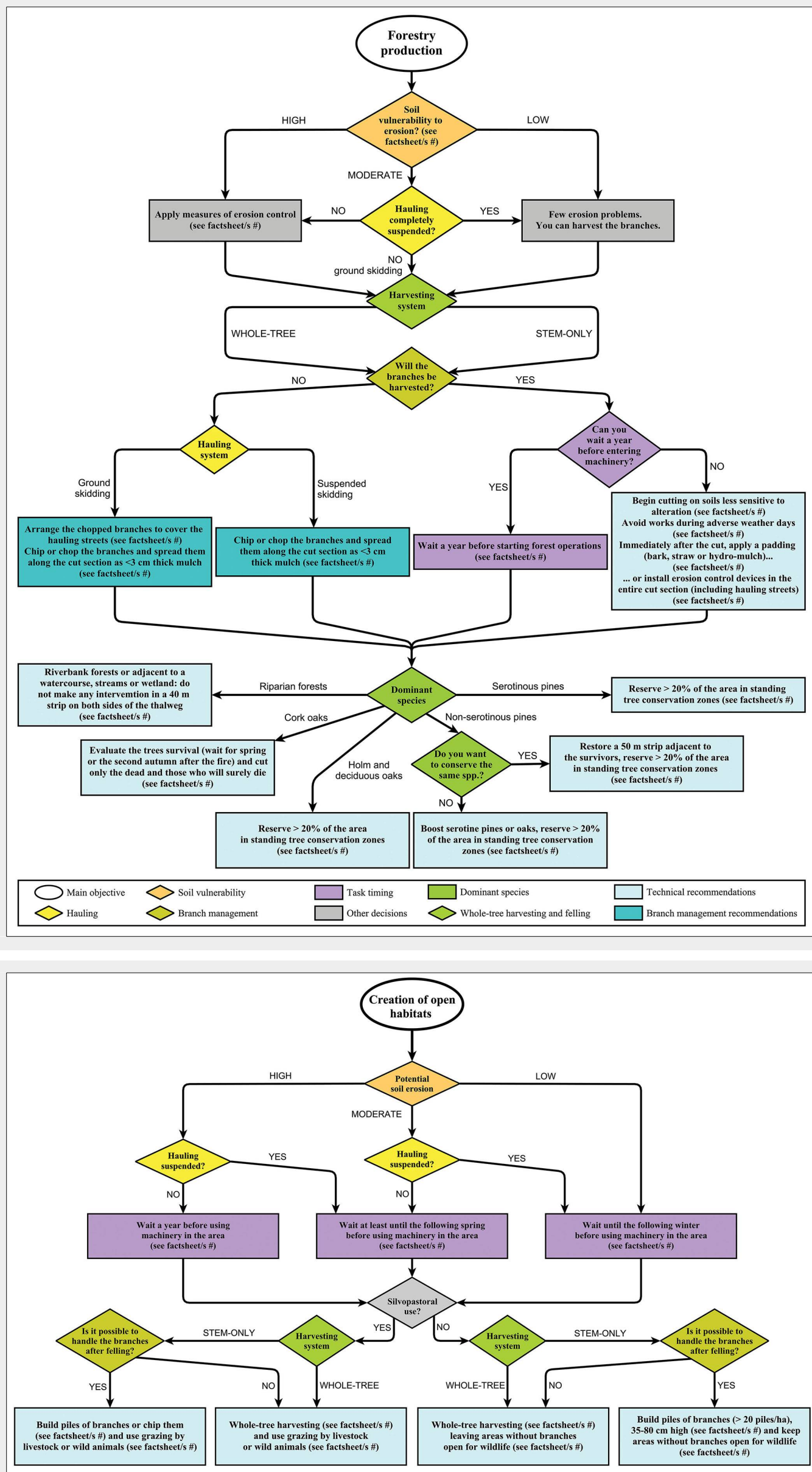

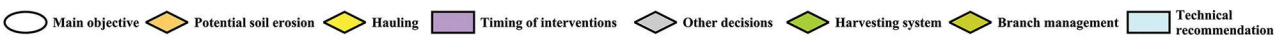

Fig. 1 - Decision-making tool for the main objective of forestry production in forests affected by wildfires. This is one of the four flowcharts for decision support, the other three being biodiversity conservation, generation of open habitats and reduction of fire risk. The combination of answers chosen by the user leads to numerical codes corresponding to the technical recommendations that are explained in the "Handbook of good practices in postwildfire management" (Mauri \& Pons 2019).

Fig. 2 - Decision-making tool for the main objective of generating open habitats in forests affected by wildfires. The combination of answers chosen by the user leads to numerical codes corresponding to the technical recommendations that are explained in the "Handbook of good practices in postwildfire management" (Mauri \& Pons 2019). 
maps if available. Management recommendations for salvage logging will then vary depending on the values (low, medium, high or very high) attained by these parameters (Alloza et al. 2014). The higher the values, the more environmentally restrictive recommendations will be for the site. Due to its preventive nature, immediate post-fire environmental assessment should be compulsory before salvage logging.

The second recommended action for the whole burned area is to decide the amount of burned wood to be retained, as standing dead trees or cut canopies, and its location. Retaining wood not only allows the preservation of organic biomass that would foster biodiversity and ecosystem recovery, but it would also imply areas free of harvesting machinery circulation. Few studies exist (see below) about the optimal amount and spatial distribution of wood to be left on site after a fire. The quantities can be set as an absolute measure (in tons $\mathrm{ha}^{-1}$ or $\mathrm{m}^{3} \mathrm{ha}^{-1}$ ), when the amount of coarse woody debris (CWD) in unmanaged conditions is well known, or otherwise as a relative amount of the burned wood found after the fire (in \%). Brown et al. (2003) proposed retaining between 0 and 90 tons of wood ha-1 according to the forest typology and management objectives. Another threshold proposed is to retain the amount of wood equivalent to the quantity of CWD that occurs naturally in unmanaged forests, for example, between 9 and $32 \mathrm{~m}^{3}$ $\mathrm{ha}^{-1}$, depending on the forest type, in Mediterranean forests of the Apenines in Italy (Lombardi et al. 2008). For boreal forests in eastern Canada, preserving 30\% of the burned trees at the regional scale and at least $15 \%$ for individual burned areas has been proposed (Nappi et al. 2011). Other studies recommend a minimum of $10 \%$ of burned tree retention (Ginzburg \& Steinberger 2012, Leverkus et al. 2014). Unlogged areas should include the margins of water courses, areas vulnerable to erosion and burned trees within unburned or lightly burned vegetation patches.

The third recommendation deals with the spatial distribution of the retained wood within the managed land. Most of retained trees (90-95\%) should be preserved in clumps, since this favours ecosystem services such as seed dispersal by vertebrates. The rest (5-10\%) can be scattered trees that generate structural heterogeneity. We also propose conserving a variable extent of unlogged areas depending on the burned area size. For all fire sizes, unlogged areas should encompass a $40 \mathrm{~m}$-wide strip around water courses and wetlands, 30-60 m-wide strip downhill on the fire perimeter, areas with high soil erosion potential and with high fire severity on the soil, unburned vegetation patches and unburned litter patches, or groups of 10-20 standing dead trees if no unburned patches remain. For fires larger than 10 ha, unlogged areas should also encompass a 30-60 m-wide strip uphill on the fire perimeter, patches of standing dead trees of at least $50 \times 100$ $\mathrm{m}$, and south slopes with poor soils and few stones. For fires larger than 100 ha, unlogged areas should encompass, in addition, patches of standing dead trees of at least $200 \times 200 \mathrm{~m}$, which can be located in fragile areas or in zones that would anyway provide marginal economic profits (Nitschke 2005, Koivula \& Spence 2006, Pinzon et al. 2012).

As a general recommendation, when salvage logging is done by whole tree harvesting, $20 \%$ of standing dead trees should be preserved in logged areas. However, when only logs are harvested, this retention can be replaced by leaving woody debris on site as piles of branches. The reason is that the canopy without leaves (since leaves are burned or fall down after fire), amounts to around $20 \%$ of the tree biomass in Mediterranean forests (CREAF 1997). Therefore, conserving branches on site is similar, in terms of woody debris biomass, to retaining $20 \%$ of the burned trees. Branches can be conserved scattered or piled up. Both have benefits for biodiversity, although the benefited species can be different (Herrando et al. 2009, Bros et al. 2011), with piles providing important shelter for vertebrates and concentrating the ecological services they offer (Rost et al. 2010, 2012a). On the other hand, manual pile building increases economic costs ( $\mathrm{Ca}$ stillo-Escrivà et al. 2019) and this has to be taken into account in decision-making processes. Mechanical pile building is a cheaper option when pile structure is not an issue (M. Garfella, Balma Forestal SLP, pers. comm.).

These actions should be planned for the whole burned area and are described regardless of land ownership. When a fire encompasses several tenants, the forest authorities may assume the role of forest planner and coordinate the affected forest owners to reach an agreement between them in order to implement these actions. Examples of this procedure involve municipal and county councils in Catalonia. The benefits can then be distributed among landowners participating in the plan based on the amount of land owned and managed, so that those who will assume higher wood retention on their plots would not retrieve fewer economic benefits from salvage logging (D. Meya, Generalitat de Catalunya, pers. comm.).

\section{Post-fire forest planning and management recommendations at the stand level}

Once post-fire environmental evaluation has been performed and the amount and location of the retained burned wood have been decided, it is time to focus on planning and management at the stand level. The Handbook identifies seven "ecosystem objectives" that are meaningful at the stand level: (i) to foster the regeneration of plant cover by accelerating vegetation recovery, also to resume wood production (this will indirectly benefit soil conservation - Slesak et al. 2015 - and speed up the return of organisms and ecosystem services); (ii) to reduce the soil erosion that can follow wildfire and salvage logging; (iii) to preserve soil fertility after fire and during logging operations by conserving the soil nutrients found in the form of ashes and organic matter; (iv) to conserve invertebrate fauna and recover the conditions for recolonization; ( $v$ ) to conserve vertebrate fauna, both to preserve resilient vertebrates and promote short- and long-term recolonization; (vi) to reduce the risk of subsequent high-intensity fires; and (vii) to preserve the quality of water courses and riverine habitats.

Forest managers and forest owners should decide which ecosystem objective they want to prioritize when planning salvage logging. If two were chosen, Handbook users should look for coincident, complementary and contradictory recommendations among objectives. Coincident and complementary recommendations are the best supported practices. For contradictory recommendations, the user has to choose one of them or a middle ground. One example is the recommended amount and distribution of woody debris, much larger and aggregate when focusing on vertebrate conservation than when the accent is on fire risk prevention. In the Handbook, the recommendations for each one of these ecosystem objectives are divided, when enough information is available, into a general section (recommendations applicable to any condition of a given ecosystem objective) and one or more specific sections, corresponding to vegetation types (for ecosystem objectives i to iii), animal groups of interest (for ecosystem objectives iv and v), no specific section (in ecosystem objective vi) and a combination of vegetation types and soil restoration (for ecosystem objective vii). The total number of sections (i.e., sheets of recommendations for best practices) is 20 (Tab. 2).

In order to ease the consultation by practitioners, and when information was available, the recommendations have been grouped within each of the 20 sections. Grouping included specific forestry activities and environmental or management variables at the stand level: whole-tree harvesting, stem-only harvesting (with or without on-site tree processing), tree felling without timber extraction, felling timing, felling location, felling intensity, hauling system, weather conditions before and during logging, stand slope, livestock breeding, site preparation in case of tree or shrub planting, and other specific forestry activities.

The selection of the most appropriate recommendations for best practices is facilitated by the decision-making tool explained under "The path towards best practices of post-fire salvage logging". As mentioned, this tool guides the manager 
Tab. 2 - Number of recommendations at the stand level to be considered when planning salvage logging, per ecosystem services provided and specific habitat/biodiversity sections.

\begin{tabular}{|c|c|c|}
\hline Ecosystem service & Specific section & $\begin{array}{l}\text { Number of } \\
\text { recommendations }\end{array}$ \\
\hline \multirow{7}{*}{$\begin{array}{l}\text { Foster the regeneration } \\
\text { of plant cover }\end{array}$} & General recommendations & 11 \\
\hline & Serotinous pines & 7 \\
\hline & Non-serotinous pines & 5 \\
\hline & Holm and deciduous oaks & 8 \\
\hline & Cork oak & 10 \\
\hline & Understory vegetation & 1 \\
\hline & Conversion towards open habitats & 17 \\
\hline \multirow[t]{3}{*}{ Reduce soil erosion } & General recommendations & 12 \\
\hline & Pine forests & 2 \\
\hline & Eucalyptus plantations & 2 \\
\hline \multirow[t]{2}{*}{ Preserve soil fertility } & General recommendations & 10 \\
\hline & Eucalyptus plantations & 2 \\
\hline \multirow{2}{*}{$\begin{array}{l}\text { Conserve invertebrate } \\
\text { fauna }\end{array}$} & Soil and litter fauna & 9 \\
\hline & Saproxylic fauna and bark beetles & 8 \\
\hline \multirow{3}{*}{$\begin{array}{l}\text { Conserve vertebrate } \\
\text { fauna }\end{array}$} & Birds & 8 \\
\hline & Mammals & 12 \\
\hline & Amphibians and reptiles & 7 \\
\hline $\begin{array}{l}\text { Reduce the risk of } \\
\text { subsequent fires }\end{array}$ & General recommendations & 10 \\
\hline \multirow{2}{*}{$\begin{array}{l}\text { Preserve the quality of } \\
\text { water courses and } \\
\text { riverine habitats }\end{array}$} & Riparian forests and streams & 10 \\
\hline & $\begin{array}{l}\text { Erosion control works near water } \\
\text { courses }\end{array}$ & 10 \\
\hline
\end{tabular}

through a series of questions and leads to recommendations at the stand and landscape levels. Questions related to timing are based on the supposition that fires happen during summer, currently the most common case in the Mediterranean Basin. To reduce soil erosion during operations, we recommend waiting one year before entering with machinery in the burned area, or at least until the end of the rainy season, which is more realistic for the harvesting economic viability (the wood will gradually worsen its technological properties and loose economical value). Waiting time can be increased from 4 to 12 months, depending on potential soil erosion (at least 4 months for low, 8 months for medium and 12 months for high potential soil erosion. Moreover, the felling operations can affect tree regeneration when they interact with mast years and germination, due to mechanical injuries to seedlings and saplings (Ascoli et al. 2013).

Although wildfire is not a reason per se for modifying the forest management objectives of a property, managers and forest owners may consider the accidental habitat alteration as a potential opportunity to achieve new goals. These can include restoring degraded ecosystems, controlling invasive species or favouring natural vegetation that is better adapted to future climatic conditions (Leverkus et al. 2019). An interesting option is to take advantage of vegetation removal to create open habitats in afforested and fire-prone land- scapes to benefit both fire prevention and biodiversity conservation (Regos et al. 2018). This possibility is also addressed as a specific objective (generation of open habitats) in the decision-making tool.

\section{Experimental testing of recommendations}

Management recommendations are often based on general forest ecology and management knowledge. In other instances, recommendations arise from studies conducted under specific environmental conditions and forestry practices after fire. For this reason, it is necessary to assess the environmental impact and wood production of, at least, the most feasible commended forest operations. The next step in the process towards best practices of salvage logging was, therefore, to experimentally evaluate specific management alternatives (explained below) from the Handbook. These alternatives differed in logging intensity, type and weight of the machinery used, restrictions to machinery movement, type of harvesting, and quantity and spatial distribution of the retained wood. The treatments that are being tested and compared are: non-intervention (NI), sustainable logging (SL, using recommendations from the Handbook), and conventional salvage logging $(\mathrm{CL})$. The regional impact of sustainable logging depends on its feasibility in terms of technical choices and economic viability. For this reason, it is important that both sustainable and conventional logging stands are used not only for the experiment but also for commercial/industrial purposes.

The study is being conducted in a stone pine Pinus pinea forest, with a subcanopy of cork oaks Quercus suber, affected by a 31-ha wildfire in July 2016. The studied area comprises 12 plots, 0.7 to 3.1 ha in size, with experimental treatments interspersed among the plots (Fig. 3). An additional 0.6ha plot in a high slope area (with a $26 \%$ slope) was logged as in SL plots, but there was no harvesting: felled logs were arranged as erosion barriers and branches were piled up over the logs.

Five NI plots were established. They contained an average of $76 \mathrm{~m}^{3} \mathrm{ha}^{-1}$ of snags and debris and $35 \mathrm{~m}^{3} \mathrm{ha}^{-1}$ of live trees. No logging, understory thinning or stock breeding took place in these plots. Four SL plots provided $55 \mathrm{~m}^{3} \mathrm{ha}^{-1}$ of wood, $63 \%$ of the existing wood volume (Fig. 3) using management recommendations from the handbook. Tree felling was done manually with chainsaws eight months after fire. Parallel logging trails, 3-m wide and separated from each other by $15 \mathrm{~m}$, were defined after cutting the burned understory, so that the machinery could only move through these trails and not trample on the whole plot. Harvesting was stem only, the canopies from the felled trees were cut off, branches cut to a maximum length of $3 \mathrm{~m}$ and left on site as piles of branches. Piles were distributed rather evenly at a density of 54 piles ha ${ }^{-1}$ and had an average area of $9.4 \mathrm{~m}^{2}$ and height of $0.97 \mathrm{~m}(\mathrm{~N}=237$ piles). Additional wood retention was achieved by preserving all cork oaks that were resprouting from branches at the time of logging and all pines that had at least 50\% of green canopy and were likely to survive. No retention of standing dead trees was applied due to the relatively small size of interventions. Suspended hauling was used, logs being forwarded with a selfloading trailer pulled by a forest tractor. This set was light, weighing $12.7 \mathrm{t}$ on 8 wheels at a maximum load of $6 \mathrm{t}$ of timber. Ground skidding was scarcely used, only in steeper places that the tractor could not reach. Harvested logs were intended for sawmill, biomass or firewood depending on their characteristics. Finally, three CL plots were established, where trees were felled with chainsaws eighteen month after fire. Whole-tree harvesting was applied, with no tree retention apart from living trees, i.e., cork oaks resprouting from branches and pines having more than half green canopy. The harvested wood in these plots was $96 \mathrm{~m}^{3} \mathrm{ha}^{-1}, 91 \%$ of the existing volume (Fig. 3). After felling of trees, a forwarder and a caterpillar with a grapple were used for hauling. Both machines freely moved around the stand. Trees were stored on the road close to the plots, chipped three months later and the resulting biomass was transported to the forest company.

We are currently monitoring indicators of 
Fig. 3 - Experimental plots of burned Mediterranean pine forests in Blanes, Spain (burned area of $31 \mathrm{ha}$ ) and wood volumes retained and harvested for the three forest treatments: non-intervention; sustainable logging with retention of living trees, stem-only harvesting and canopies cut and piled up on site, and conventional logging with whole-tree harvesting and retention of living trees only.

soil compaction, erosion and fertility, wood biomass, tree condition and decay, plant regeneration, ant, beetle and spider communities, bird and mammal occupancy patterns and acorn removal by rodents in the study area (see Tab. S1 in Supplementary material for an expanded list of indicators used). Data obtained will be analysed with the main aim of comparing the results between the three experimental treatments and, when possible, between micro-sites. These include the comparison of open ground, under shrubs and under piles for the arthropod communities and for seed dispersal. For the monitoring of soil physical characteristics and plant regeneration, machinery tracks and sites outside tracks will be compared (see Tab. S2 in Supplementary material). The temporal scale will consider not only interannual environmental variability, but also differences in dates of logging (2017 in SL vs. 2018 in CL) and longer-term processes like the fall of dead trees and decay of branch piles.

\section{Results and future prospects}

An important conclusion of the review we conducted is that most studies only compare conventional post-fire salvage logging with non-intervention, and seldom with a third treatment consisting of conventional logging without timber harvesting. Studies analysing post-fire logging practices designed to reduce their environmental impact and that could be viable from a commercial perspective are rare (Koivula \& Schmiegelow 2007, Ritchie et al. 2013, Santana et al. 2016). These studies are fundamental to provide evidence for al- ternatives to the classical debate between conventional salvage logging and non-intervention. A further step would be to produce systematic reviews and meta-analyses of relevant studies to get a global view of the consequences of alternative postfire management strategies and identify knowledge gaps (Leverkus et al. 2018). Likewise, a greater involvement of forest stakeholders in producing guidelines for post-fire management and restoration is fundamental for proposing viable options for the sector (Mavsar et al. 2012).

Due to current knowledge gaps, the evidence behind some recommendations of the Handbook may still be weak. However, the urgency to reduce the impact of current practices justifies, in our opinion, recommending less impacting interventions even if they have not been assessed in each region. The experimental study we are conducting is therefore convenient. It will provide a comparative evaluation of the ecological impact of non-intervention, sustainable logging and conventional salvage logging on a recently burned pine forest. Although the study is based on a single area and forest type, the strengths are the replicated experiment with interspersed treatments, the monitoring of multiple ecological indicators, and the assessment of treatments intended to be usable by managers. Detailed information of the forest operations has also been gathered to perform a basic economic assessment of each management option. However, the lack of replicated burned areas prevents a general economic evaluation, where stand area, forest type, timber volume, operation costs, carbon footprint, etc. are taken into account. The inclusion of additional study areas will be necessary to generalise the results and to conduct proper economic studies.

A further aim of the experimental study is to provide simplified methods and indicators for environmental assessment before and after logging. To this end, we will count on a 1- to 4-year evaluation of around 70 ecosystem indicator variables of soil, dead wood, vegetation, animal biodiversity, and seed predation and dispersal (Tab. S1 in Supplementary material). The 10-20 most informative and easy-to-measure variables will be selected and guidelines will be provided for their monitoring by practitioners.

Apart from the usual academic outputs consisting of scientific papers and communications, results are being spread by means of panels located in the experimental areas, videos and workshops in the field with stakeholders. More importantly, some recommendations from the handbook are already being promoted among landowners by the forest administration in Catalonia (Martin 2019). These recommendations include: (i) allowing two months after fire before logging starts for management planning and to avoid the highest erosion risk; (ii) retaining $20 \%$ of standing dead trees or leave canopies on site as piles of branches ( $>25$ piles of around $5 \mathrm{~m}^{2}$ ha-1); (iii) not logging unburned forest patches; (iv) not destroying dry stone walls; (v) using logging trails, separated from each other by at least $12 \mathrm{~m}$, for machinery movement; (vi) avoiding the use of heavy ma- 
chinery on unprotected and wet soils to prevent soil compaction; (vi) building erosion barriers on slopes steeper than $25 \%$; (viii) taking extreme precautions on fragile soils. These recommendations could become mandatory to forests owners and managers benefited by public subsidies or in protected lands. They have therefore the potential to influence the management of large areas.

Likely, the process explained here can be adapted and used in other socio-ecological contexts to improve forest management after disturbances. Similar processes in diverse regions would help to generalize the knowledge on the topic and to connect scientists and practitioners.

\section{Final remarks}

The media focus on wildland fires, and especially on extreme wildfire events (Tedim et al. 2018) contrasts with the lack of interest in the management of burned forests. Apart from soil erosion and forest regeneration processes, national legislations do little to regulate post-fire salvage logging and to impede the complete removal of dead trees over large areas (Mavsar et al. 2012). Moreover, economic incentives from government bodies to promote specific sustainable forestry practices have been reduced in recent years due to the economic context. Therefore, management decisions mainly depend on the agreement between forest owners and private companies. The large scale application of best post-fire salvage logging practices needs, however, a different context (Pons \& Rost 2017). Stakeholders have to be aware of positive and negative effects of salvage logging and of the importance of woody debris for ecosystem functioning and its regeneration after fire. National legislation has to ensure natural regeneration, for example making post-fire planning measures mandatory in official forest management plans, or including formal requirements to ensure retention of biological legacies in harvested areas. Conventional salvage logging has to be banned or strictly regulated in forests devoted to conservation (Thorn et al. 2018). Administrative procedures need improvements to allow for landscape-level forestry planning after large wildfires and on-site monitoring of activity. Interdisciplinary teams of scientists and practitioners are needed to generate bestpractice guidelines adapted to specific regions. Authorities and managers may assess the economic needs to assist owners and communities to perform best practices, that can be subsidized by EU Rural Development Program or other funding instruments. Wood certification, stewardship agreements, or other enticements of collaboration should also be used to promote the application of these best practices on public and private lands. Finally, much more debate to help improve the management of Mediterranean burned forests is needed.

\section{Acknowledgments}

PP developed the idea and wrote the first draft. EM and PP conceived the Handbook explained in this paper. PP, CT and JMB conceived and conducted the Blanes experiments. All authors contributed to the writing, and read and approved the final manuscript.

We thank Marc Garfella for his help in designing and carrying out the experimental treatments, and David Meya, Aitor Goñi and staff from Bosquerols Cooperative for providing fundamental information. Students and scientists involved in the Blanes project helped us with fieldwork, laboratory and data analyses. We also thank Gemma Vila, Pilar Eijo and Maria Sibecas for project administration, and Erola Pons for help with Fig. 3. This study was funded by projects: CGL2014-54094-R from the Spanish Ministry of Economy and Competitiveness, 56300632017 P4 from the Generalitat de Catalunya (DARPAM) and EAFRD, and MPCUdG2016/084 from the University of Girona, Spain.

\section{References}

Alloza JA, García S, Gimeno T, Baeza J, Vallejo R, Rojo L, Martínez A (2014). Guía técnica para la gestión de montes quemados. Protocolos de actuación para la restauración de zonas quemadas con riesgo de desertificación [Technical guide for the management of burned forests. Action protocols for the restoration of burned areas at risk of desertification]. Ministerio de Agricultura, Alimentación y Medio Ambiente, Madrid, Spain, pp. 185. [in Spanish]

Ascoli D, Castagneri D, Valsecchi C, Conedera M, Bovio G (2013). Post-fire restoration of beech stands in the Southern Alps by natural regeneration. Ecological Engineering 54: 210-217. - doi: 10.1016/j.ecoleng.2013.01.032

Azeria ET, Ibarzabal J, Hébert C, Boucher J, Imbeau L, Savard J-PL (2011). Differential response of bird functional traits to post-fire salvage logging in a boreal forest ecosystem. Acta Oecologica 37: 220-229. - doi: 10.1016/j.actao.20 11.02.005

Boulanger Y, Sirois L, Hebert C (2010). Distribution of saproxylic beetles in a recently burnt landscape of the northern boreal forest of Quebec. Forest Ecology and Management 260: 11141123. - doi: 10.1016/j.foreco.2010.06.027

Bros V, Moreno-Rueda G, Santos X (2011). Does postfire management affect the recovery of Mediterranean communities? The case study of terrestrial gastropods. Forest Ecology and Management 261: 611-619. - doi: 10.1016/j.for eco.2010.11.014

Brown JK, Reinhardt ED, Kramer KA (2003). Coarse woody debris: managing benefits and fire hazard in the recovering forest. USDA Forest Service, Rocky Mountain Research Station, Ogden, UT, USA, pp. 16. [online] URL: http:// books.google.com/books?id=MPMTAAAAYAAJ Castillo-Escrivà A, López-lborra GM, Cortina J, Tormo J (2019). The use of branch piles to assist in the restoration of degraded semiarid steppes. Restoration Ecology 27: 102-108. - doi: 10.1111/rec.12704

Castro J, Moreno-Rueda G, Hódar JA (2010). Ex- perimental test of postfire management in pine forests: impact of salvage logging versus partial cutting and nonintervention on bird-species assemblages. Conservation Biology 24: 810-819. - doi: 10.1111/j.1523-1739.2009.01382.x

Cervera T, Pino J, Marull J, Padró R, Tello E (2019). Understanding the long-term dynamics of forest transition: from deforestation to afforestation in a Mediterranean landscape (Catalonia, 1868-2005). Land Use Policy 80: 318-331. - doi: 10.1016/j.landusepol.2016.10.006

CREAF (1997). Sistema d'Informació dels Boscos de Catalunya (SIBosC) [Forest Information System of Catalonia]. Centre de Recerca Ecològica i Aplicacions Forestals - CREAF, Bellaterra, Spain. [in Catalan]. [online] URL: http://www. creaf.uab.es/iefc/pub/Catalunya/Biomassa.htm Franklin JF, Lindenmayer D, MacMahon JA, McKee A, Magnuson J, Perry DA, Waide R, Foster D (2000). Threads of continuity. Conservation in Practice 1: 8-17. - doi: 10.1111/j.1526-4629.2000. tbo0155.x

García-Morote F, Martínez-García E, Andrés-Abellán $\mathrm{M}$, Caballero $\mathrm{E}$, Miettinen $\mathrm{H}$, López-Serrano F (2017). Direct seeding of Pinus halepensis Mill. for recovery of burned semi-arid forests: implications for post-fire management for improving natural regeneration. Forests 8 (9): 353 . doi: $10.3390 / f 8090353$

Ginzburg O, Steinberger $Y$ (2012). Salvage logging versus natural regeneration post-fire practices in a forest: soil chemical and microbial aspects. Open Journal of Ecology 2: 29-37. - doi: 10.4236/oje.2012.21004

Herrando S, Brotons L, Guallar S, Sales S, Pons P (2009). Postfire forest management and Mediterranean birds: the importance of the logging remnants. Biodiversity and Conservation 18: 2153-2164. - doi: 10.1007/s10531-009-9579-5 Izhaki I, Adar M (1997). The effects of post-fire management on bird community succession. International Journal of Wildland Fire 7: 335342. - doi: 10.1071/WF9970335

James CE, Krumland B (2018). Immediate postforest fire salvage logging, soil erosion, and sediment delivery. Forest Science 64 (3): 246267. - doi: 10.1093/forsci/fxx013

Koivula MJ, Schmiegelow FKA (2007). Boreal woodpecker assemblages in recently burned forested landscapes in Alberta, Canada: effects of post-fire harvesting and burn severity. Forest Ecology and Management 242 (2-3): 606618. - doi: 10.1016/j.foreco.2007.01.075

Koivula M, Spence JR (2006). Effects of post-fire salvage logging on boreal mixed-wood ground beetle assemblages (Coleoptera, Carabidae). Forest Ecology and Management 236 (1): 102112. - doi: 10.1016/j.foreco.2006.09.004 Leverkus AB, Lorite J, Navarro FB, Sánchez-Cañete EP, Castro J (2014). Post-fire salvage logging alters species composition and reduces cover, richness, and diversity in Mediterranean plant communities. Journal of Environmental Management 133: 323-331. - doi: 10.1016/j.jenvman.2 013.12.014

Leverkus AB, Benayas JMR, Castro J (2016). Shifting demographic conflicts across recruitment cohorts in a dynamic post-disturbance landscape. Ecology 97: 2628-2639. - doi: 10.1002 lecy. 1527

Leverkus AB, Rey Benayas JM, Castro J, Boucher 
D, Brewer S, Collins BM, Donato D, Fraver S, Kishchuk BE, Lee E-J, Lindenmayer DB, Lingua E, Macdonald E, Marzano R, Rhoades CC, Royo A, Thorn S, Wagenbrenner JW, Waldron K, Wohlgemuth T, Gustafsson L (2018). Salvage logging effects on regulating and supporting ecosystem services - a systematic map. Canadian Journal of Forest Research 48: 983-1000. doi: 10.1139/cjfr-2018-0114

Leverkus $A B$, Murillo PG, Doña VJ, Pausas JG (2019). Wildfires: Opportunity for restoration? Science 363 (6423): 134-135. - doi: 10.1126/scien ce.aaw2134

Lindenmayer DB, Burton PJ, Franklin JF (2008). Salvage logging and its ecological consequences. Island Press, Washington, USA, pp. 227.

Lombardi F, Lasserre B, Tognetti R, Marchetti M (2008). Deadwood in relation to stand management and forest type in Central Apennines (Molise, Italy). Ecosystems 11: 882-894. - doi: 10.1007/s10021-008-9167-7

Malvar MC, Silva FC, Prats SA, Vieira DCS, Coelho COA, Keizer JJ (2017). Short-term effects of post-fire salvage logging on runoff and soil erosion. Forest Ecology and Management 400: 555-567. - doi: 10.1016/j.foreco.2017.06.031

Marañón-Jiménez S, Castro J (2013). Effect of decomposing post-fire coarse woody debris on soil fertility and nutrient availability in a Mediterranean ecosystem. Biogeochemistry 112: 519535. - doi: 10.1007/s10533-012-9744-x

Marañón-Jiménez S, Castro J, Querejeta Jl, Fernandez-Ondono E, Allen CD (2013). Post-fire wood management alters water stress, growth and performance of pine regeneration in a Mediterranean ecosystem. Forest Ecology and Management 308: 231-239. - doi: 10.1016/j.for eco.2013.07.009

Martin A (2019). Com actuar correctament en aquelles zones afectades per un incendi forestal? [How to act properly in those areas affected by a forest fire?]. Silvicultura 80: 45-46. [in Catalan]

Mauri E, Pons P (2016). Fichas de buenas prácticas para la gestión forestal postincendio [Factsheets of good practices in post-wildfire forest management]. Proyecto Anifog, Universitat de Girona, Girona, Spain, pp. 116. [in Spanish]

Mauri E, Pons P (2019). Handbook of good practices in post-wildfire management. Proyecto Anifog, Universitat de Girona, Girona, Spain, pp. 169. [online] URL: http://anifog.wixsite.com /anifog/blank

Mavsar R, Varela E, Corona P, Barbati A, Marsh G (2012). Economic, legal and social aspects of post-fire management. In: "Post-Fire Management and Restoration of Southern European Forests" (Moreira F, Arianoutsou M, Corona P, De las Heras J eds). Series "Managing Forest Ecosystems", vol. 24, Springer, Dordrecht, the Netherlands, pp. 45-78. - doi: 10.1007/978-94007-2208-8 3

Moreira F, Arianoutsou M, Vallejo VR, de las Heras J, Corona P, Xanthopoulos G, Fernandes $P$, Papageorgiou $K$ (2012). Setting the scene for post-fire management. In: "Post-Fire Management and Restoration of Southern European Forests" (Moreira F, Arianoutsou M, Corona P,
De las Heras J eds). Series "Managing Forest Ecosystems", vol. 24, Springer, Dordrecht, the Netherlands, pp. 1-19. - doi: 10.1007/978-94-0072208-8_1

Nabuurs G-J, Delacote P, Ellison D, Hanewinkel $M$, Lindner $M$, Nesbit $M$, Ollikainen $M$, Savaresi A (2015). A new role for forests and the forest sector in the EU post-2020 climate targets. From Science to Policy 2. European Forest Institute, Joensuu, Finland, pp. 32. - doi: 10.36333/ fsO2

Nappi A, Déry S, Bujold F, Chabot M, Dumont MC, Duval J, Drapeau P, Gauthier S, Brais S, Peletier J, Bergeron I (2011). La récolte dans les forêts brûlées - Enjeux et orientations pour un aménagement écosystémique [Harvesting in burned forests - Challenges and guidelines for ecosystem management]. Ministère des Ressources naturelles et de la Faune, Québec, Canada, pp. 51. [in French]

Nitschke CR (2005). Does forest harvesting emulate fire disturbance? A comparison of effects on selected attributes in coniferous-dominated headwater systems. Forest Ecology and Management 214: 305-319. - doi: 10.1016/j.foreco.200 5.04.015

Pau Costa Foundation (2012). L'ecologia del foc i el règim d'incendis en la gestió del paisatge [Fire ecology and fire regime in landscape management]. PCF Journal Club, Llers, Spain. [in Catalan] [online] URL: http://www.paucosta foundation.org/journal-club-lecologia-del-foc-iel-regim-dincendis-en-la-gestio-del-paisatge/

Pinzon J, Spence JR, Langor DW (2012). Responses of ground-dwelling spiders (Araneae) to variable retention harvesting practices in the boreal forest. Forest Ecology and Management 266: 42-53. - doi: 10.1016/j.foreco.2011.10.045

Pons P, Rost J (2017). The challenge of conserving biodiversity in harvested burned forests. Conservation Biology 31: 226-228. - doi: 10.1111/ cobi.12767

Regos A, Hermoso V, Amen M, Guisan A (2018). Trade-offs and synergies between bird conservation and wildfire suppression in the face of global change. Journal of Applied Ecology 55: 2181-2192. - doi: 10.1111/1365-2664.13182

Ritchie MW, Knapp EE, Skinner CN (2013). Snag longevity and surface fuel accumulation following post-fire logging in a ponderosa pine dominated forest. Forest Ecology and Management 287: 113-122. - doi: 10.1016/j.foreco.2012.09.001 Rost J, Clavero M, Bas JM, Pons P (2010). Building wood debris piles benefits avian seed dispersers in burned and logged Mediterranean pine forests. Forest Ecology and Management 260: 79-86. - doi: 10.1016/j.foreco.2010.04.003 Rost J, Bas JM, Pons P (2012a). The importance of piling wood debris on the distribution of bird-dispersed plants in burned and logged Mediterranean pine forests. International Journal of Wildland Fire 21: 79-85. - doi: 10.1071/WF10 068

Rost J, Clavero M, Brotons L, Pons P (2012b). The effect of postfire salvage logging on bird communities in Mediterranean pine forests: the benefits for declining species. Journal of Applied Ecology 49: 644-651. - doi: 10.1111/j.1365-26 64.2012.02127.x
San-Miguel-Ayanz J, Durrant T, Boca R, Libertà G, Branco A, De Rigo D, Ferrari D, Maianti P, Artés Vivancos T, Oom D, Pfeiffer H, Nuijten D, Leray $T$ (2019). Forest fires in Europe, Middle East and North Africa 2018. Joint Research Centre, Ispra, Italy, pp. 161.

Santana VM, Gonzalez-Pelayo O, Maia PAA, Varela $M E$, Valdecantos A, Vallejo VR, Keizer JJ (2016). Effects of fire recurrence and different salvage logging techniques on carbon storage in Pinus pinaster forests from northern Portugal. European Journal of Forest Research 135: 1107-1117. - doi: 10.1007/s10342-016-0997-0 Schelhaas MJ, Nabuurs GJ, Schuck A (2003). Natural disturbances in the European forests in the 19th and 2oth centuries. Global Change Biology 9: 1620-1633. - doi: 10.1046/j.1365-2486.2003.00 684.x

Slesak RA, Schoenholtz SH, Evans D (2015). Hillslope erosion two and three years after wildfire, skyline salvage logging, and site preparation in southern Oregon, USA. Forest Ecology and Management 342: 1-7. - doi: 10.1016/j.foreco.201 5.01 .007

Smith HG, Sheridan GJ, Lane PNJ, Bren L (2011). Wildfire and salvage harvesting effects on runoff generation and sediment exports from radiata pine and eucalypt forest catchments, south-eastern Australia. Forest Ecology and Management 261: 570-581. - doi: 10.1016/j.forec 0.2010.11.009

Tedim F, Leone V, Amraoui M, Bouillon C, Coughlan M, Delogu G, Fernandes P, Ferreira C, MCCaffrey S, McGee T, Parente J, Paton D, Pereira M, Ribeiro L, Viegas D, Xanthopoulos G (2018). Defining extreme wildfire events: difficulties, challenges, and impacts. Fire 1 (1): 9. - doi: 10.3390/fire1010009

Thorn S, Bässler C, Brandl R, Burton PJ, Cahall R, Campbell JL, Castro J, Choi C-Y, Cobb T, Donato DC, Durska E, Fontaine JB, Gauthier S, Hebert C, Hothorn T, Hutto RL, Lee E-J, Leverkus AB, Lindenmayer DB, Obrist MK, Rost J, Seibold $S$, Seidl R, Thom D, Waldron $K$, Wermelinger $B$, Winter M-B, Zmihorski M, Müller J (2018). Impacts of salvage logging on biodiversity - a meta-analysis. Journal of Applied Ecology 55: 279-289. - doi: 10.1111/1365-2664.12945

Vacchiano G, Stanchi S, Marinari G, Ascoli D, Zanini E, Motta R (2014). Fire severity, residuals and soil legacies affect regeneration of Scots pine in the Southern Alps. Science of the Total Environment 472: 778-788. - doi: 10.1016/j.scitot env.2013.11.101

Wolf-Crowther M, Mozes C, Laczko R (2011). Forestry in the EU and the world: a statistical portrait. Eurostat, Luxembourg, pp. 107.

\section{Supplementary Material}

Tab. S1 - List of ecological indicators.

Tab. S2 - Levels of variation and potential levels of comparison of ecological indicators used in the study.

Link: Pons_3380@supplo01.pdf 